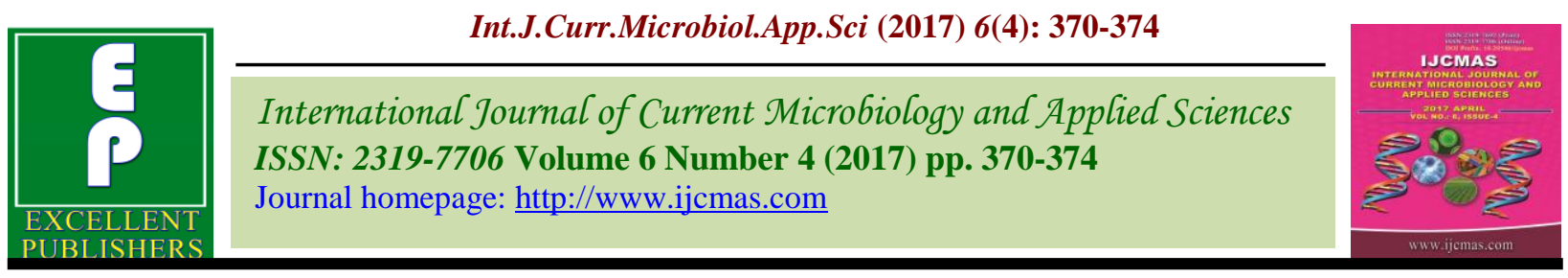

Original Research Article

https://doi.org/10.20546/ijcmas.2017.604.041

\title{
Knowledge and Attitude of the Farmers towards Sprinkler Irrigation System in Raikia Block of Kandhamal District of Odisha
}

\author{
D.V. Singh ${ }^{1^{*}}$ and Nidhi Sinha ${ }^{2}$ \\ ${ }^{1}$ Senior Scientist \& Head, KVK, Kandhamal, OUAT, Bhubaneswar, India \\ ${ }^{2}$ Scientist, (Home Science), KVK, Gaya, BAU Sabour, India \\ *Corresponding author
}

\begin{tabular}{|c|c|}
\hline & 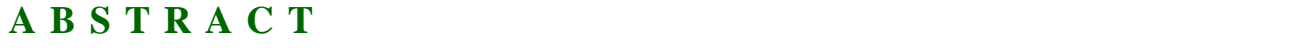 \\
\hline Keywords & \multirow{4}{*}{$\begin{array}{l}\text { Sprinkler irrigation is still in its infancy in India and there is a need to make it popular } \\
\text { among the farmers. Even though there is a phenomenal growth in the area under sprinkler } \\
\text { irrigation, a lot of work is still to be done to explain and convince the farmers, especially } \\
\text { those in the dry land area about the high potentialities of this new system. The present } \\
\text { study was conducted in Rakia block of Kandhamal district in Odisha, which was selected } \\
\text { purposively. The data were collected through pre-tested schedule for } 120 \text { respondents } \\
\text { selected randomly. The collected data were tabulated, analyzed and interpreted with the } \\
\text { help of appropriate statistical tools. Majority of farmers }(56.67 \%) \text { were found having } \\
\text { medium level of knowledge and attitude }(58.33 \%) \text { towards sprinkler irrigation system. } \\
\text { Education and annual income was found positive and significant correlation with their } \\
\text { knowledge of sprinkler irrigation system. Education had positive and significant } \\
\text { association with their attitude towards sprinkler irrigation system. }\end{array}$} \\
\hline $\begin{array}{l}\text { Knowledge, } \\
\text { Attitude, Sprinkler } \\
\text { irrigation system }\end{array}$ & \\
\hline Article & \\
\hline $\begin{array}{l}\text { Accepted: } \\
\text { 02 March } 2017 \\
\text { Available Online: } \\
10 \text { April } 2017\end{array}$ & \\
\hline
\end{tabular}

\section{Introduction}

Land and water are important natural resources, which play an important role in agricultural production. Due to the scarce conditions of water for irrigation, many parts of the land were unutilized or underutilized. This is mainly due to the fact that the rainfall is irregular and uneven in many parts of country. Odisha is no exception under this situation, shortage of water is one of the main problems in Odisha agriculture. Therefore, efficient use of available water has become extremely important which can be done through sprinkler irrigation.

Sprinkler irrigation is still in its infancy in India and there is a need to make it popular among the farmers. Even though there is a phenomenal growth in the area under sprinkler irrigation, a lot of work is still to be done to explain and convince the farmers, especially those in the dry land area about the high potentialities of this new system. The main purpose of this study was to get a clearcut picture of the present situation of the knowledge and attitude towards sprinkler irrigation system in Odisha especially in Kandhamal district where there are problems of scarcity as well as abundance of water. The present study "Knowledge and attitude of the farmers towards sprinkler irrigation system at Rakia block in Kandhamal district of Odisha" was planned with the following specific objectives: 1. To determine the socioeconomic characteristics of the respondents. 
2. To ascertain the knowledge and attitude of the respondents towards sprinkler irrigation system. 3. To ascertain the relationship between the selected socio-economic characteristics and knowledge and attitude towards sprinkler irrigation system.

\section{Materials and Methods}

The present study was purposively undertaken in the Rakia block in Kandhamal district of Odisha state. Twelve villages were purposively selected from the selected block on the basis of higher number of farmers having sprinkler irrigation system. From each selected village, 10 farmers were selected randomly by making a sample of 120 respondents.

The present study was confined to ex-postfacto research design. The independent variables were measured by using suitable scale and procedure adopted by various researchers in past with due modification.

The dependent variable taken in this study was knowledge and attitude towards sprinkler irrigation system which measured by developed structured schedule on the basis of the attitude scale developed by Likert's (1932).

An interview schedule was developed according to objectives of study and the data were collected by arranging personal interview with 120 respondents.

The collected data were classified, tabulated and analyzed in order to make the findings meaningful. A simple ranking technique applied to measure the problems and suggestions to overcome problems of adoption of sprinkler irrigation system. The statistical tools used to analyze the data were percentage, mean, score and standard deviation.

\section{Results and Discussion}

\section{Socio-economical characteristics of the respondents}

The socio-economical, characteristics of the respondents were studied and the data have been given in table 1 .

\section{Socio-economical characteristics of the respondents}

Majority $(58.33 \%)$ of the respondents had medium level of overall socio-economic status, followed by 21.67 per cent and 20.00 per cent of respondents with low and high level of socio-economic status, respectively.

Knowledge and attitude of the respondents towards sprinkler irrigation system

Table 2 indicates that the majority $(56.67 \%)$ of the respondents possessed medium level of knowledge followed by 23.33 per cent and 20.00 per cent of respondents possessed high and low level of knowledge about sprinkler irrigation system, respectively. The similar results were observed by Thore (2008).

Majority (58.33 \%) of respondents had medium level of attitude towards sprinkler irrigation system. While, 24.17 and 17.50 per cent respondents had high and low level of attitude towards sprinkler irrigation system, respectively. The similar results were observed by Hiremath (1993).

Relationship between the selected socioeconomic characteristics, knowledge, and attitude towards sprinkler irrigation system

In table 3 out of four independent variables of the respondents, variable viz., education and annual income was found to have positive and significant correlation with their knowledge of sprinkler irrigation system. 
Table.1 Distribution of respondents by the socio-economic status

\begin{tabular}{|c|c|c|}
\hline \multicolumn{3}{|c|}{ Age } \\
\hline Category & Frequency & Percentage \\
\hline Young (Up to 35 years) & 16 & 13.33 \\
\hline Middle (36-50) & 84 & 70.00 \\
\hline Old (Above 50 Years) & 20 & 16.68 \\
\hline \multicolumn{3}{|c|}{ Education } \\
\hline Illiterate & 47 & 39.17 \\
\hline Primary (up to $7^{\text {th }}$ standard) & 29 & 24.17 \\
\hline Secondary $\left(8^{\text {th }}\right.$ to $10^{\text {th }}$ standard $)$ & 21 & 17.50 \\
\hline Higher $\left(11^{\text {th }}\right.$ to $12^{\text {th }}$ standard $)$ & 14 & 11.67 \\
\hline College and above & 09 & 7.50 \\
\hline \multicolumn{3}{|c|}{ Land Holding } \\
\hline Small (up to 2 Acre) & 23 & 19.17 \\
\hline Medium (between 2.1 to 4.0 Acre) & 63 & 52.50 \\
\hline Large (More than 4.0 Acre) & 34 & 28.33 \\
\hline \multicolumn{3}{|c|}{ Annual Income } \\
\hline Low (up to $76,000 /-$ ) & 17 & 14.17 \\
\hline Medium $(76,001 /-2,44,000 /-)$ & 82 & 68.33 \\
\hline High (above $2,44,000 /-$ ) & 21 & 17.50 \\
\hline \multicolumn{3}{|c|}{ Social Participation } \\
\hline No membership & 72 & 60.00 \\
\hline Membership in one organization & 16 & 13.33 \\
\hline $\begin{array}{l}\text { Membership in more than one } \\
\text { organization }\end{array}$ & 29 & 24.17 \\
\hline Holding position in organization & 03 & 2.50 \\
\hline \multicolumn{3}{|c|}{ Extension Contact } \\
\hline Low (up to 21 score) & 26 & 21.67 \\
\hline Medium (between 22 to 25 ) & 66 & 55.00 \\
\hline High (above 26 score) & 28 & 23.33 \\
\hline \multicolumn{3}{|c|}{ Mass Media Exposure } \\
\hline Low (up to 17 score) & 25 & 20.83 \\
\hline Medium (between 18 to 21 score) & 72 & 60.00 \\
\hline High (above 21 score) & 22 & 19.17 \\
\hline \multicolumn{3}{|c|}{ Source of Irrigation } \\
\hline Tube -well & 46 & 38.33 \\
\hline Canals & 45 & 37.50 \\
\hline Tube-well and Canal & 29 & 24.17 \\
\hline \multicolumn{3}{|c|}{ Overall Socio-economic Status } \\
\hline Low (up to 17 score) & 26 & 21.67 \\
\hline Medium (between 18 to 21 score) & 70 & 58.33 \\
\hline High (above 21 score) & 24 & 20.00 \\
\hline Mean $=19.48$ & \multicolumn{2}{|c|}{$\mathrm{SD}=1.77$} \\
\hline
\end{tabular}


Table.2 Distribution of the respondent according to their knowledge and attitude towards sprinkler irrigation system $(n=120)$

\begin{tabular}{|c|c|c|c|}
\hline \multicolumn{5}{|c|}{ Knowledge Level } \\
\hline Category & Knowledge Score & Frequency & Percentage \\
\hline Low & Up to 10 & 24 & 20.00 \\
\hline Medium & $11-14$ & 68 & 56.67 \\
\hline High & Above to 14 & 28 & 23.33 \\
\hline \multicolumn{5}{|c|}{ Attitude Level } \\
\hline Mean $=\mathbf{1 2 . 3 3}$ & Frequency & Percentage \\
\hline Category & Attitude Score & 21 & 17.50 \\
\hline Low & Up to 26 & 70 & 58.33 \\
\hline Medium & 27-30 & 29 & 24.17 \\
\hline High & Above to 30 & SD = 2.52 \\
\hline
\end{tabular}

Table.3 Relationship between the selected socio-economic characteristics and knowledge and attitude towards sprinkler irrigation system $(n=120)$

\begin{tabular}{|c|c|c|}
\hline \multicolumn{2}{|c|}{ Knowledge level } \\
\hline S. No. & Variables & Correlation coefficient('r' value) \\
\hline 1. & Age & $-0.05760^{\mathrm{NS}}$ \\
\hline 2. & Education & $0.26394^{* *}$ \\
\hline 3. & Land holding & $-0.16873^{*}$ \\
\hline 4. & Annual income & $0.29783^{* *}$ \\
\hline \multicolumn{2}{|c|}{ Attitude level } \\
\hline 1. & Age & $0.01595^{\mathrm{NS}}$ \\
\hline 2. & Education & $0.19782^{*}$ \\
\hline 3. & Land holding & $-0.23809^{* *}$ \\
\hline 4. & Annual income & $-0.19926^{*}$ \\
\hline
\end{tabular}

*= Significant at 0.05 level of probability. ${ }^{* *}=$ Significant at 0.01 level of probability.

NS= Non Significant

The one variables land holding of the farmers were negatively but significantly associated with their knowledge of sprinkler irrigation system. Remaining age had negative and nonsignificant association observed with their knowledge of sprinkler irrigation system.

Out of four independent variables of the respondents, one variables education had positive and significant association observed with their attitude towards sprinkler irrigation system. The variables viz. land holding, annual incomes of the farmers were negatively but significantly associated with their attitude towards sprinkler irrigation system. Remaining variable viz., age was found to have negative and non-significant correlation with their attitude towards sprinkler irrigation system.

In conclusion majority of the farmers belonged to middle age group having primary 
education and illiterate. These farmers had medium size of land holding. They had maximum number of respondents no membership in any social organization. These farmers had income in between Rs. 76, 001 to Rs. 2, 44,000 and used canals and tube-well as an irrigation sources. These farmers had medium level of extension contact, mass media exposure. These farmers possessed medium level of knowledge about sprinkler irrigation system. Majority of the farmers were found to have medium level of attitude of sprinkler irrigation system. The variables, education and annual income of the farmers were positive and significantly associated with their knowledge of sprinkler irrigation system. The variables viz. educations of the farmers were positive and significantly associated with their attitude towards of sprinkler irrigation system. Regarding problems of sprinkler irrigation system, majority of the farmers facing the problems like heavy initial investment for the installation of sprinkler irrigation system, difficulties in getting loans, rate of interest in loans in high and unavailability of technical guidance in time, these problems can be solved by certain extension strategies like organization of training programme, establishment of co-ordination and availability of day-to-day farm services to the door of farmers.

\section{References}

Chaudhary, S. 2013. "Knowledge and attitude of the paddy growers towards system of Rice intensification at Meja block of Allahabad district in Uttara Pradesh". Unpublished M.Sc. (Agri.) Dissertation, SHIATS, Allahabad, U.P.

Hiremath, V.M. 1993. A study of Knowledge and Attitude of the Farmers towards Horticultural Development Programme in Pune District. Unpublished M.Sc (Agri.) Thesis (Unpub.), M.P.K.V, Rahuri (M. S).

Sharnagat, P.M. 2008. Attitude of Beneficiaries towards National Horticulture Mission. Unpublished M.Sc (Agri.) Thesis (Unpub.), Dr. P.D.K.V, Akola (M.S).

Suthar, K.D. 2010. "Socio-economic impact of drip irrigation system among the farmers of Sabarkantha district of Gujarat state". Unpublished M. Sc. (Agri.) thesis, S.D.A.U., Gujarat.

Thore, V.V. 2008. "Knowledge and Attitude of Beneficiaries towards National Horticulture Mission in Marathwada Region". Unpublished M.Sc (Agri.) Thesis (Unpub.); M.A.U, Parbhani (M.S).

\section{How to cite this article:}

Singh, D.V. and Nidhi Sinha. 2017. Knowledge and Attitude of the Farmers towards Sprinkler Irrigation System in Raikia Block of Kandhamal District of Odisha. Int.J.Curr.Microbiol.App.Sci. 6(4): 370-374. doi: https://doi.org/10.20546/ijcmas.2017.604.041 